Digital Press Social Sciences and Humanities

Tourist Experience in Mandala Pepadhanging Jagad Travel Package for Heritage Tourism Development in Borobudur Temple Compound

Dian Arymami, Hendrie Adji Kusworo and Muhamad Sidiq Wicaksono

Proceeding of Indonesia Heritage Tourism Forum 2019 (IHTF 2019)

Dewi Pratika Ayu Dhira Pradati (eds) 


\title{
Tourist Experience in Mandala Pepadhanging Jagad Travel Package for Heritage Tourism Development in Borobudur Temple Compound
}

\author{
Dian Arymami i, ${ }^{*}$, Hendrie Adji Kusworo ${ }^{2}$, and Muhamad Sidiq Wicaksono ${ }^{3}$ \\ 1 Department of Communication Studies, Faculty of Social and Political Science, Universitas Gadjah Mada, Yogyakarta, Indonesia \\ 2 Tourism Studies Programme, Postgraduate School, Universitas Gadjah Mada, Yogyakarta, Indonesia \\ 3 Department of Languages, Arts and Culture Management, Vocational College, Universitas Gadjah Mada, Yogyakarta, Indonesia \\ *e-mail: arymami@ugm.ac.id
}

\begin{abstract}
Tourist experience has become a focal point in tourism management studies. Unforgettable, special, and spectacular travel experience is challenged to encourage not only in quantity side in the material form of numbers of visitors but also develop values that maintain, preserve, and conserve heritage tourism principles. Development of heritage tourism by integrating the concept of tourism and cultural conservation has become one of the efforts carried in Borobudur Temple Compound. One of the core elements in this effort was the development of travel experience with channeling narratives in tourism practices. The Borobudur Temple Compound holds a bountiful of narratives that have been buried in decades. Reviving the narratives around Borobudur becomes essential in managing heritage tourism and preserving cultural heritage. Selected narratives collected in the legend of Borobudur are soon to be integrated into tourism practice. Focusing on the increase of effectiveness in creating travel experience; transfer knowledge and values of these selected stories or narratives are studied to grasp tourist satisfaction determined by tourist's psychological flow. Thus, these experiences become essential in evaluating heritage tourism development through narrations in Borobudur Compounds. This researchbased article presents the significance of travel experience into two main focus: the narratives and travel experience with the narrative storytelling, including creativity in creating tour amenities, and management from tour guide competencies from two selected Borobudur narrative. Using survey and focus group interview the outcomes shows a positive tourist experience satisfaction in which can be used as a foundation to thrust the development of heritage tourism policies in Indonesia.
\end{abstract}

\section{Keywords}

Borobudur, heritage tourism, thematic travel, tourist psychological flow, tourist satisfaction

\section{Introduction}

Borobudur Temple Compound as an Indonesian cultural masterpiece is an international destination. Build as Mahayana Buddhism religious complex at Syailendra Dynasty, Borobudur becomes the largest religious complex at its time and an avant-garde monument that marks the greatness of Mataram Kuno Kingdom. The presence of Borobudur Temple is not only important as a witness of the history in the Indonesian nation's journey but also marks a global change in the development of Buddhist beliefs. To this day, Tibetan priests believe that Borobudur Temple is a place where Atisha, the Buddhist announcer of Tibet, once studied religious knowledge (Magetsari, 2017). Thus, the position of the Borobudur Temple Compound is very multidimensional by its meaning in the community: as a historical heritage site, a tourism site, a source of livelihood, and also a Buddhist religious shrine following that mandated in the Cultural Heritage Law 2010.

Since it was rediscovered in 1814, Borobudur Temple Compound continues to undergo reconstruction, renovation, redefinition, and reconciliation efforts by parties that come and go according to the mindset and conditions of the era. In 1973, UNESCO announced the Borobudur Temple Compounds as a World Heritage Site which brought this historical monument to the world stage. This was also a turning point for the temple's management. Since the Borobudur Temple Compound listed as World Heritage Sites, Indonesia is required to meet the standards of protection of cultural heritage that has been set in the 
UNESCO World Heritage Convention. It is not only obliged to protect the physical aspects of the building, but also to continuously improve tourism in the Borobudur Temple Compound. The development of cultural tourism that balances between the numbers of visitors with the practical protection of cultural heritage is still constrained. An integrated concept that can combine the two interests is a crucial issue to be addressed. A questioned issue that can be answered by strengthening the development of heritage tourism.

The Borobudur Temple Compound is inseparable from the site's narratives; the soul of a tourist attraction. Unfortunately, the richness of Borobudur's narrative contextually has decreased and increasingly disappearing along with thousands of visitors across generations. Exploring and reviving the legend of Borobudur is an essential effort in revitalizing the value of world heritage and avoiding sites in becoming 'dead' objects. The scientific and non-scientific approach has become one of the efforts in reexcavating the legends stored by the temple building and the surrounding area. The findings of experts from the fields of archeology, history, literature, anthropology, geology, geography, and so on provided extraordinary material and richness of the narratives and legend in the Borobudur Temple. The findings are connected, knitting of legends based on science and science which are further arranged in 8 narrative travel packages that are educative, interactive, and inspiring (Arymami, Buana, \& Muhibar, 2019).

Research on destinations, markets, industry, and all elements of tourism has been produced by many tourism experts in this country. However, Indonesia is still lagging in the development of tourism compared to neighboring countries. Researchers, practitioners, the government usually explains the backwardness of Indonesia's tourism due to poor destination management, poor quality marketing, and promotion, poor infrastructure and facilities support, lack of support from local governments or communities. So that the review of the quality of service itself is still limited.

Indonesia can compile seven powerful principles in tourism development called Sapta Pesona. Sapta Pesona tourism principle consists of safety, orderly, clean, cool, beautiful, welcoming, and memorable. Sapta Pesona's principle from one to four is the result of the embodiment of the destination physical indicators but the fifth and six principles (welcoming and memorable) are two of the seven charms that have not been much discussed by experts and tourism planners, though, both of these points are equally important and even become the most important point as a reason for tourists returning to the destination. Reviving the Borobudur narrative is an essential effort that is not only important in the process of tourism management but also the preservation of cultural heritage and further caring for humanity and civilization. The eight narratives that have been compiled in the travel thematic of the Borobudur Temple Region are now starting to be managed for the tourist experience. The purpose of thematic travel through narration is no longer just informative but fosters knowledge, is educational, entertaining, values fiber, and transports the emotions of its listeners through a legend. A living and continuing story, a story that triggers each visitor to become a storyteller; preservation of a continuously developing heritage of knowledge; improve the experience of the tourists need to have their success evaluated for the development of heritage tourism in the Borobudur Temple Area. The significance of understanding the tourism experience in thematic traveling developed by the tourism management of the Borobudur Temple Area can be a basis for encouraging the tourism industry's business in the Borobudur Temple Area as well as implementing the development of heritage tourism.

\section{Methods}

The research methods used to assess the experience of tourists in thematic traveling in the Borobudur Temple Area are the survey and focus group interview methods. The survey method was applied to get respondents' perceptions and aspirations related to tourist experiences in the thematic travel of the Borobudur Temple Area. Survey methods are needed because of their ability to gather information from the public about an issue (Engel, Jann, Lynn, Scherpenzeel, \& Sturgis, 2014; Fowler Jr., 2013). In this case, a survey will be conducted on thematic travel tourists in the Borobudur Temple Area. The focus group interview method is used to obtain a depth of information from community members, academics, and tourism industry organizers. Through the focus group interview method, as stated by Kamberlis \& Dimitriadis (2013), it is possible to obtain a diversity of ideas among informants, a diversity of perspectives, as well as a diversity of cross perspective data inter-informants in a comprehensive manner.

The research subject to study the Borobudur tourist experience was carried out with two selected travel themes namely: Sudhana Kinari and Walking with the Stars. The number of selected research subjects was 
21 people consisting of men (28\%) and women (72\%) in the age range 18-21. The age selection of visitors is adjusted to the target market and contextual generation.

\section{Literature Review}

Experience in tourism is interpreted in various ways by tourism experts. Tung \& Ritchie (2011) stated that the experience of traveling is a subjective evaluation of an individual to events related to tourism activities in him starting from the preparation to travel, as long as there is destined and after the trip. Therefore, tourism planners should facilitate the development of an environment of destinations that increase the allure of tourists to create an unforgettable traveling experience in a positive sense.

Planning a destination with a high allure for tourists is a complicated job. A manager or destination manager cannot fully provide an unforgettable traveling experience for tourists directly. This is because each experience is unique and very subjective even though a tourism planner has tried to provide good service, interesting events, and various activities. Memorable tourism activities have close links with psychology and anthropology. Therefore, in this literature review, we need to listen to some opinions from psychology and anthropology-based tourism experts about the meaning and meaning of unforgettable tourism (memorable experiences in hospitality and travel). Gunter (1987) identifies a variety of terminology to discuss travel experiences based on the level of easy to remember or not remember. Besides, according to Woodside, Caldwell, \& Albers-Miller (2004) has researched a positive impression of a tourist attraction is the main reason for tourists to return to the destination and get infected with others. In line with previous opinions, Ritchie \& Crouch (2003) viewed from a managerial point of view, a good destination manager is when they consider aspects of these unforgettable memories in tourism planning. This is the advantage for a destination compared to other destinations

\subsection{Tourism Satisfying Experience}

A satisfying experience can be interpreted as harmonization of needs and circumstances, while dissatisfaction is defined as the distance between expectations and experience (Ryan, 1997). Therefore a tourism planner should be able to use tourist satisfaction considerations. So planners need to establish policies to reduce the risk of reduced tourist satisfaction. Nevertheless, tourism planners sometimes experience difficulties in implementing policies to reduce tourist dissatisfaction. This happens because it's so complicated to understand tourist satisfaction. If Noe (1987) analyzes that expression of tourists, for example, happy laughter is an indicator of tourist satisfaction, but Pearce (2005) says that satisfaction is an attitude that concerns affective, cognitive, and habitual elements. Therefore everyone has different indicators to show satisfaction. Otto \& Richie (1995) argue that the satisfaction of a tourism service is a level of subjectivity, emotional, and response from the services provided. Thus, it is really complicated to understand tourist satisfaction. The results of a closer study are from Arnould \& Price (1993) who examined the experience of rafting, writing that tourists mention three dimensions of satisfaction, namely; relationships with nature, interactions with friends, family or new people, and self-development.

From the managerial point of view, Pine and Gilmore (1998) changed the direction of the target of a management paradigm, namely from management that emphasizes service towards management that builds experience. This is driven by the awareness that experience is subjective which is only experienced by individuals that involve emotional, physical, spiritual, and intellectual level interactions. He defines four domains of experience namely entertainment, education, aesthetics, and adventure. Pine and Gilmore (1998) write that the experience of an adventurer (escapist) involves the feelings of the customer both active participation and immersion in the concept of the flow of experience written by Cary's (2004) about serendipity has little or no impact on their experience as a tourist who looking at the Grand Canyon from a cliff, an escapist will transform into an aesthetic experience (Pine \& Gilmore, 1998).

Pine and Gilmore (1998) compiled five points which they called an experience design principle that consisted of; the theme of experience, the impression of harmony with positive impressions, reducing negative impressions, merging in memory by involving the five senses. Their opinion is widely used by tourism researchers in various countries that have developed tourism. 


\subsection{Thematic Traveling: Interconnection, Memories, and Experience}

The experience is interpreted through narrative concepts. Narrative is defined as a knowledge structure consisting of thematic and temporary sequences related to events. The experience is then conveyed in story-telling which then becomes popular for analyzing the memories and experiences of tourists (Woodside, 2010). Schank (1999) mentions that basic human memories are like a script, and each individual usually uses his own interpretation based on experience into a story. In the tourism literature, storytelling has been used to analyze stories and themes in interpretive settings (Moscardo, 2010). For example, researchers usually ask participants to name specific types of experiences such as back-packing, to find out the impact of their journey on their identity (Desforges, 2000), or in functions of tourism development such as service quality (Obenour, Pattenson, Pedersen, \& Pearson, 2006).

The importance of storytelling in understanding travel experiences can be influenced by several factors. Based on Moscardo (2010), tourists create stories during their trip. Then the story told by them becomes the effect of the entire destination brand. Therefore destination management must be supported by the design and creation of consistency between the experience of what is heard and the theme of the destination (Pine \& Gilmore, 1998). Then, storytelling forms memories of impressions of events of all time (McGregor \& Holmes, 1999). Stories will usually be stored in memory and can be opened at any time when there is a clue from both the individuals involved in the experience and the location visited.

\section{Finding and Discussion}

The subjective tourism experience of the individual towards expected tourism activities is an important point in tourism development. Four important domains of experience seen through entertainment, education, aesthetics, and adventure were invited by Pine and Gilmore (1998). Two Borobudur trips titled Sudhana Kinari and Walking with the Stars are the two themes used in this study, are the two new travel themes sought in the Borobudur Temple Area in the relationship of cultural heritage tourism.

The narration of Sudhana Kinari is the theme of the journey that takes the main location in Borobudur with a love story and the value of harmonious life in the narration. Meanwhile, the narrative Walking with the Stars is a story about astronomical maps about the construction of the Borobudur temple, Mendut, and Pawon that are in the Orion Star line and the historical and historical story of Hiragana in Japan, which is centered on the location of Mendut Temple.

Travel experiences, impressions, and impressions found in tourist subjectivity are broken down through two studies; evaluation of travel narratives and experiences of travel. The concept of tourist experience on the journey narrative is seen through 5 narrative bases including cultural values, uniqueness, social values, education, and the relevance of attractions to the narration. The concept of a tourist experience on a trip seen through 5 basis stimulants consists; differentiation of experiences, travel locations, accessibility, attractions, and travel facilities. Qualitatively the impression is also collected through the Focus Group Interview to parse the value and also the negative earned by tourists.

Borobudur shows aspects of a strong narrative experience with an interval of 3.13 on a Walking journey with the Stars and very strong at an interval of 3.33 on a Sudhana Kinari trip. A description of the elements in evaluating the narrative of a tourist experience is as follows:

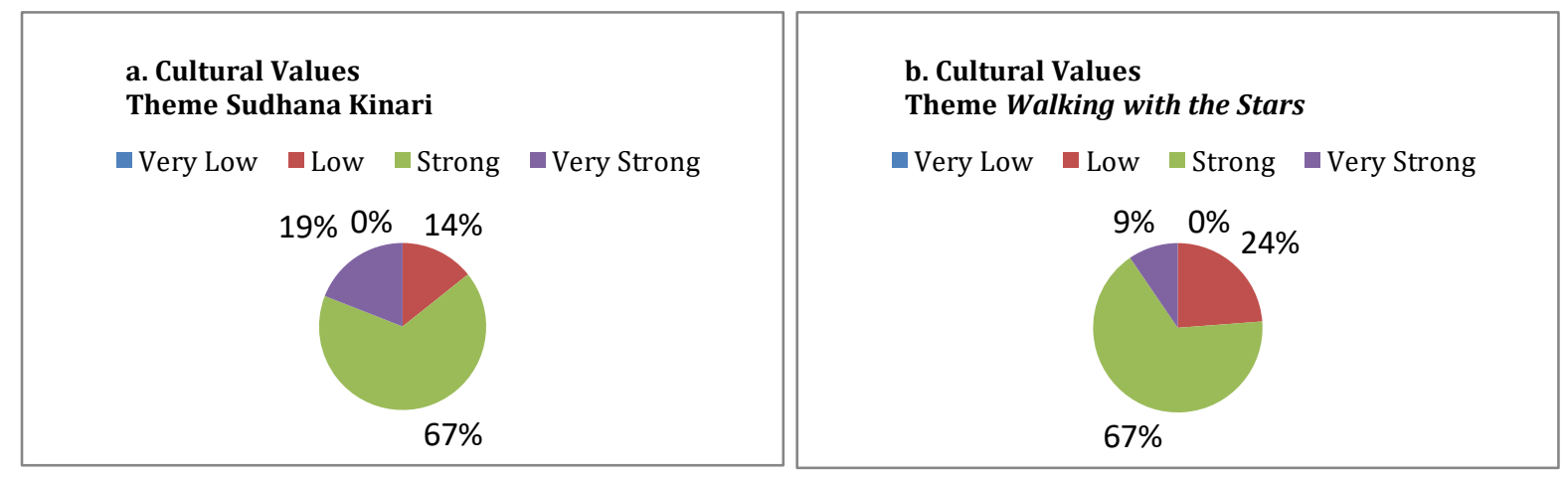

Fig. 1 Cultural Values Theme 1; a Sudhana Kinari, b Walking with the Stars 
The cultural values in the Walking with the Stars and Sudhana Kinari narratives show a narrative impression of strong cultural content with both 67\%. Even though the impression of cultural-related narrative experience is more prominent Sudhana Kinari's narration that gets 19\% is very strong experience in comparison with Walking with the Stars at 9\%, and the opinion of weak cultural values is higher in the theme of Walking with the Starts at $24 \%$ compared to with the theme of Sudhana Kinari at $14 \%$.
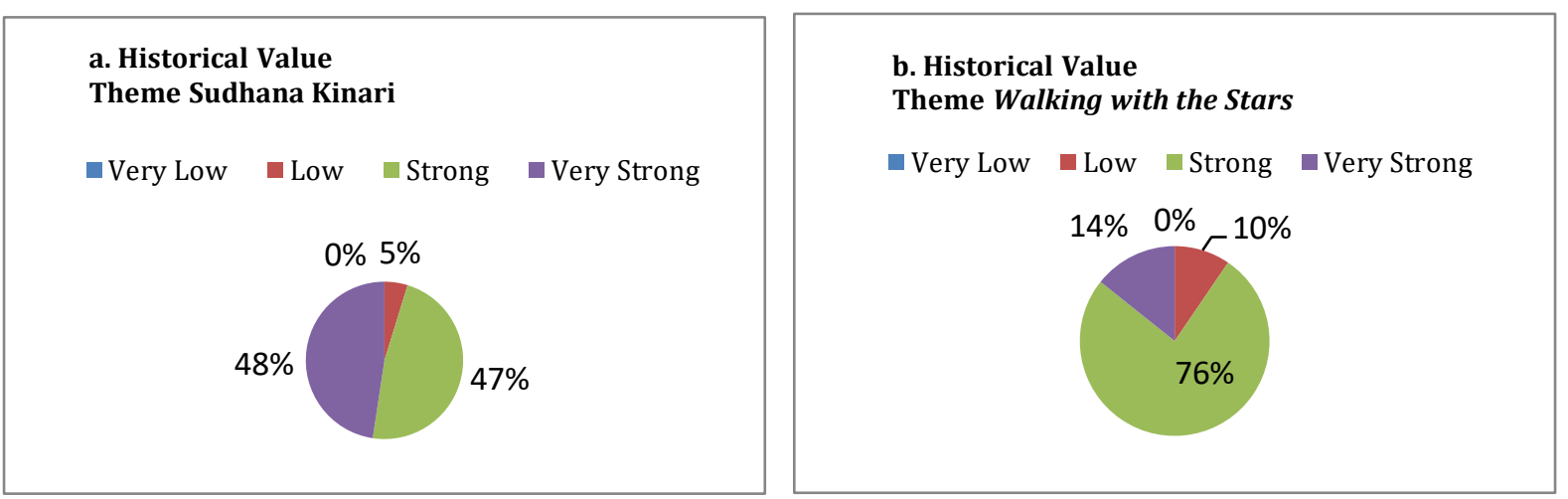

Fig. 2 Historical Value Theme 1; a Sudhana Kinari, b Walking with the Stars

Historical values in the narrative show a tendency similar to cultural values. The impression of narrative experience related to history is more prominent Sudhana Kinari's narration which gets 48\% experience is very strong in comparison with Walking with the Stars at $14 \%$.
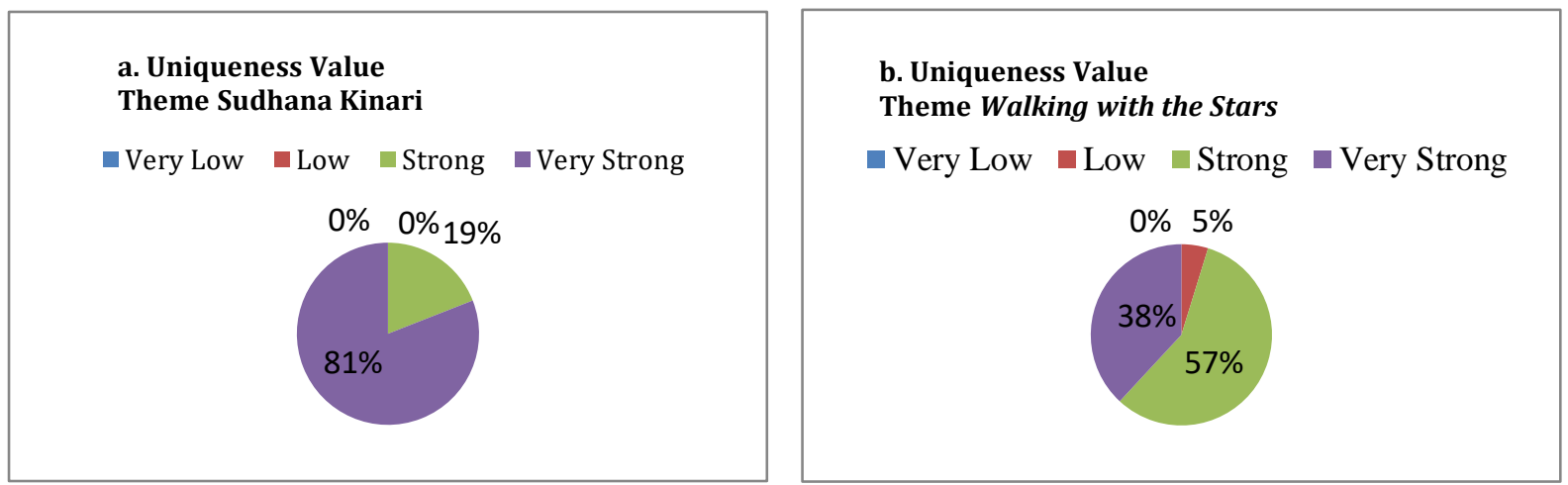

Fig. 3 Uniqueness Value Theme 1; a Sudhana Kinari, b Walking with the Stars

The unique value of narration is an important element in experiences that touch cognition and emotion. This uniqueness can be seen as an illustration of the value of newness obtained by tourists which is very significant in the management of tourist trips. Data shows a similar trend related to uniqueness in the two travel themes. The impression of uniqueness is very strong in the narration of Sudhana Kinari with $63 \%$ compared to Walking with the Stars with $57 \%$.
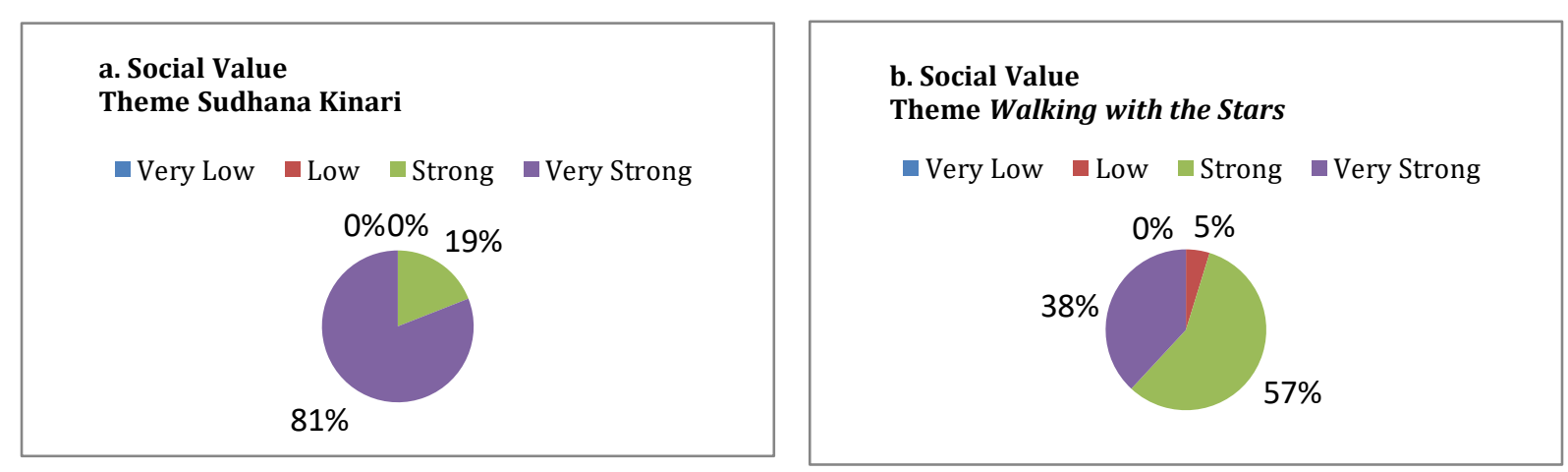

Fig. 4 Social Value Theme 1; a Sudhana Kinari, b Walking with the Stars 
Social value in narration refers to the contextual interconnection of narratives with daily and community relations. Social values become an important element in the daily interconnection of narratives which gives a stronger emphasis on the impression of involvement as human beings. Data shows the same tendency related to social values in two travel themes. The impression of a very strong social value is in the narration of Sudhana Kinari with $63 \%$ compared to Walking with the Stars with $38 \%$. This can be read with the contextualization of experiences where love stories are much closer to human daily life than astronomical narratives that may be new themes that are rarely encountered in everyday life. In this regard, correlatively can be proven with the educational value obtained by tourists shows that Walking with the Stars trip is considered very strong with a value of $76 \%$ compared to Sudhana Kinari's theme at 60\% (see chart. Educational Values).
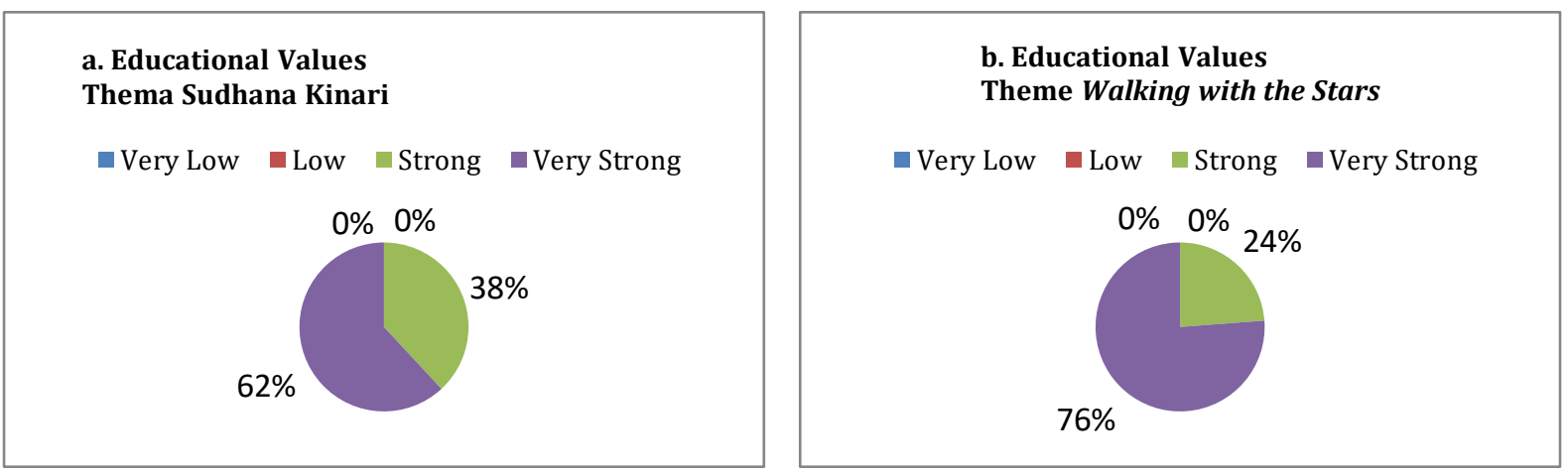

Fig. 5 Educational Value Theme 1; a Sudhana Kinari, b Walking with the Stars
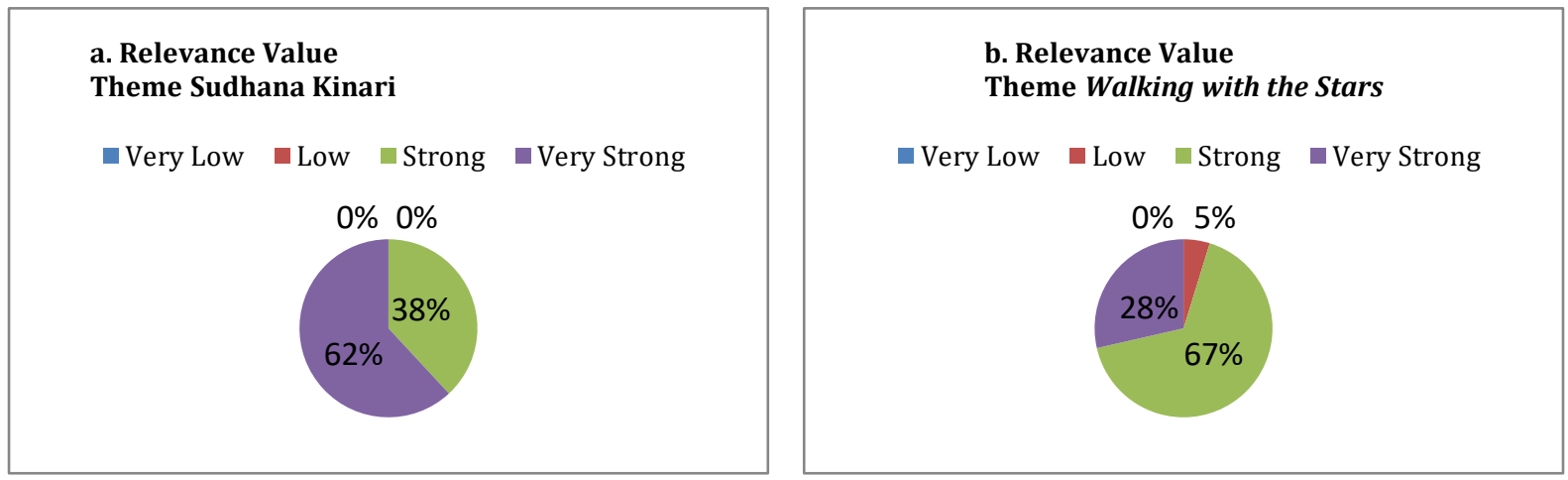

Fig. 6 Relevance Value Theme 1; a Sudhana Kinari, b Walking with the Stars

The relevance of tourism objects to the narration shows the impression of experience with a very strong tendency on the trip to Sudhana Kinari with a rate of $62 \%$ and the trip with the Stars at $35 \%$. This can be read through a number of perspectives, firstly related to the technical issues of a large location in interconnecting astronomic patterns that are difficult to imagine without a supporting medium, resulting in the relevance of the Mendut Temple object to the narrative of Walking with the Stars is weaker than Borobudur Temple with the panel available at in plain sight. Another perspective can be explored with the familiarity of the name of the Borobudur Temple which has been more famous and separate in the narrative of the Borobudur Area from the Mendut and Pawon Temples in public discourse.

Tourist experience of the trip in detail is seen through 5 basis stimulants in the form of differentiation of experiences, travel locations, accessibility, attractions, and travel facilities. Through survey data, it can be seen that the experience of traveling two thematic routes has a strong average value on both thematic trips. 

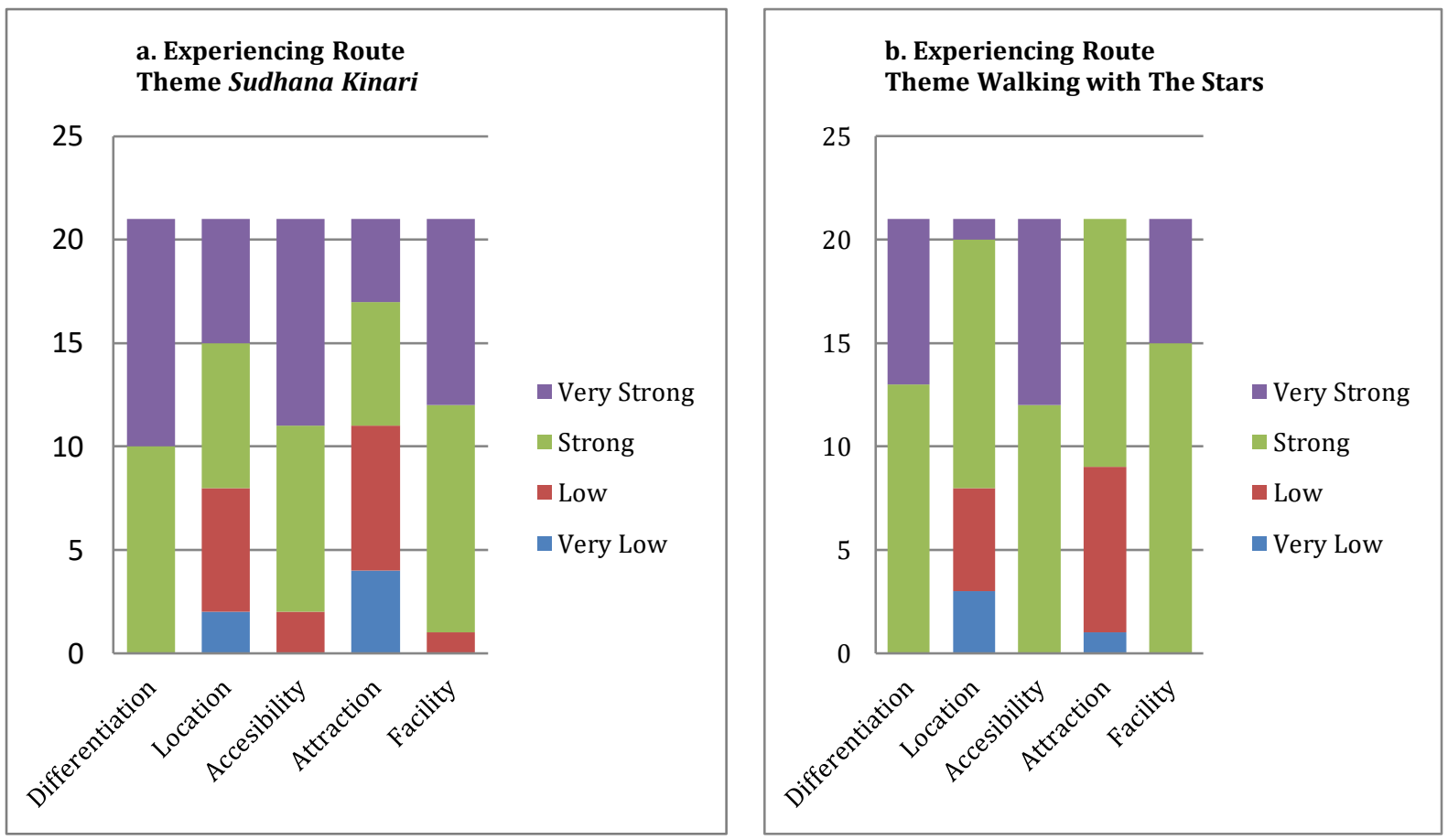

Fig. 7 Experiencing Route Theme 1; a Sudhana Kinari, b Walking with the Stars

Differentiation data that shows the uniqueness of a tourist trip in comparison to other tourist trips experienced by tourists show a very strong tendency in the theme of Sudhana Kinari travels with a value of $50 \%$ compared to Walking with the Stars. Through the above data also shows the accessibility of the location of the trip that stands out between the two thematic trips, with the tendency of Mendut Temple which is seen to be more accessible than Borobudur Temple. This can be read with the location and distance of tourist sites which are significantly different between the two temples, however, it can be seen how the impression of an attractive and varied attraction value in the love narration Sudhana Kinari obtained by visitors. The location and accessibility context are also supported by qualitative data which generally states that Sudhana Kinari's thematic journey is seen as very interesting but tiring. In both travel themes, the narrative impression that appears is slightly different from the main narrative presented. The data show that Walking with the Stars focuses on astronomical and cultural narratives, captured strongly as stories about the relationship between Mendut temples and Hiragana, reincarnations of various Buddhist forms.

While the strongest impression of the end of the story of Sudhana Kinari lies not in the power of love, but about the story of heaven, shipwreck, planet, and the geography of the Borobudur region. In general, tourists' safeguards presented in the Focus Group Interview also show a deep impression and stimulus that encourages behavior to share stories with their friends outside. This gives a positive picture of the impression of the tourist experience on the thematic narrative of traveling in the Borobudur Temple Area which is about to be developed. The desire to share narratives with outsiders shows the potential for the development of heritage tourism that is being pursued. Critics and suggestions, as well as tourist expectations that are part of the Focus Group Interview data, also provide important notes on the media and technology supporting thematic travel, specifically on reducing sound distraction related to tourist circulation, the cleanliness and aesthetics of the temple as well as the medium explanation of the images in relief.

\section{Conclusion}

The experience of traveling has become a focal point in tourism management and studies. The development of heritage tourism that integrates the concept of tourism and cultural preservation has become one of the efforts carried out in the Borobudur Temple Compounds implemented through thematic trips shows positive results from tourists. Narratives and thematic trips in the Borobudur Temple Compounds have shown an added value in the realm of education, entertainment, and experiences that touch the space of cognition, emotions to behavior. Narrative contextualization with visitor characteristics was found to be 
very relevant and could be adapted to the context of thematic travel practices. This opens up opportunities and the potential for further study of narratives in thematic journeys related to the age, generation, and social background of tourists. Studies of the background elements of tourists in perfecting thematic trips can encourage efforts to develop heritage tourism more effectively.

Acknowledgment This research is notably supported by the works of the UGM Borobudur Story Telling Team, namely; Ayudhira Pradati, Louie Buana, Nuraulia Muhibar, Raden Rucitarahma Ristiawan, Khusnul Bayu. We also thank you for the support and cooperation of this work to Sekolah Pasca Sarjana UGM and the Ministry of Tourism, Indonesia.

\section{References}

Arnould, E., \& Price, L. (1993). River magic: Extraordinary experience and the extended service encounter. Journal of Consumer Research, 20(1), 24-45.

Arymami, Buana, \& Muhibar. (2019). Legenda Borobudur: “Mandala Pepadhanging Jagad”. Jakarta: Kemenpar.

Cary, S. H. (2004). The tourist moment. Annals of Tourism Research, 31(1), 61-77.

Desforges, L. (2000). Travelling the world: Identity and world biography. Annals of Tourism Research, 27(4), 926-945.

Engel, U., Jann, P., Lynn, P., Scherpenzeel, A., \& Sturgis, P. (2014). Improving Survey Methods: Lesson from Recent Research. Paris: Routledge.

Fowler Jr., F. J. (2013). Survey Research Methods (fifth edition). London: Sage Publisher.

Gunter, B. G. (1987). The leisure experience. Selected properties. Journal of LeisureResearch, 19(2), 115-130.

Kamberlis, G., \& Dimitriadis, G. (2013). Focus Group: From Structured interviews to collective conversations. London: Routledge.

Magetsari, N. (2017). Candi Borobudur sebagai Perwujudan Dharma dalam Gandawyuha Kawedhar. The 6th Borobudur Writers and Cultural Festival Religiusitas Agama-Agama Nusantara.

McGregor, I., \& Holmes, J. G. (1999). How storytelling shapes memory and impression of relationship events over time. Journal of Personality and Social Psychology, 76(3), 403-419.

Moscardo, G. M. (2010). The shaping of tourist experience. The importance of stories and themes. In P. L. Morgan \& J. R. B. Ritchie (Eds.), $M$ (pp. 43-58). The tourism and leisure experience. Consumer and managerial perspectives . Bristol, UK: Channel View Publications.

Noe, F. P. (1987). Measurement specification and leisure satisfaction. Leisure Sciences, 9(3), 163-172.

Obenour, W., Pattenson, M., Pedersen, P., \& Pearson, L. (2006). Conceptualization of a meaning-based research approach for tourism service experiences. Tourism Management, 27, 34-41.

Otto, J., \& Richie, J. (1995). Exploring the quality of the service experience. A theoretical and empirical analysis. Advances in Services Marketing and Management, 4, 37-61.

Pearce, P. L. (2005). Tourist behaviour: Themes and conceptual schemes. Clevedon: Channel View Publications.

Pine, B. J., \& Gilmore, J. H. (1998). Welcome to the experience economy. Retrieved from Harvard Business Review website: https://hbr.org/1998/07/welcome-to-the-experience-economy 
Ritchie, J. R. B., \& Crouch, G. (2003). The competitive destination: A sustainable tourism perspective. Cambridge, MA: CABI Publishing.

Ryan, C. (1997). The tourist experience. A new introduction. London: Cassell.

Schank, R. C. (1999). Dynamic memory revisited. Cambridge, UK: Cambridge University Press.

Tung, V. W. S., \& Ritchie, J. R. B. (2011). Exploring the essence of memorable tourism experiences. Annals of Tourism Research, 38(4), 1367-1386. https://doi.org/10.1016/j.annals.2011.03.009

Woodside, A. (2010). Brand-consumer storytelling theory and research: Introduction to a psychology \& marketing special issue. Psychology \& Marketing, 27(6), 531-540.

Woodside, A., Caldwell, M., \& Albers-Miller, N. (2004). Broadening the study of tourism: Introduction to the special issue on the consumer psychology of travel/tourism behavior. Journal of Travel and Tourism Marketing, 17(1), 1-7. 